\title{
The Relationship between Religion and State in Jordan: (Historical Perspective)
}

\author{
Hani Ahmed Shboul* \\ Al Balqa'a Applied University, Assalt- Jordan
}

"Corresponding Author: Hani Ahmed Shboul, Al Balqa'a Applied University, Assalt- Jordan

\begin{abstract}
Since its establishment, the Jordanian state has been characterized as a civil, not religious in the theocratic sense. The state has not established on a religious basis, nor has its legitimacy been based on a 'religious ideology'. However, in contrast, it was not established on the basis of radical secularism, which entangles a confrontational spirit with conservative and religious trends in the society.

Jordan has maintained a 'balance' between civil and religious requirements, and preserves this trait since its inception to this time, and through generations of successive kings: Abdullah I, Talal, Hussein and Abdullah II. The country did not come out from this public line at any stage, and this balance remained a key feature of Jordan's policy.

This study aims at identifying the type of relationship between religion and state in Jordan, in other words, how the Jordanian state manages its relationship with religion.
\end{abstract}

Keywords: Jordan, King, Civil State, Balance, Secular, Religion.

\section{INTRODUCTION}

Since the establishment of the Emirate of Transjordan in 1921 by its founder, Prince Abdullah bin Al Hussein, the state has achieved a stable and unchanged 'balance' in its relationship with religion (Islam) ${ }^{1}$.

The Emirate of Transjordan was established in 1921 by the then Emir Abdullah bin al Hussein and became a British protectorate. In 1946, Jordan became an independent state officially named "The Hashemite Kingdom of Transjordan" and in 1949 the name of the state was changed to "The Hashemite Kingdom of Jordan". Emir Abdullah became king Abdullah I (the founding king).

Since its founding, Jordan has not established its legitimacy on a strictly religious "ideology", and Islamic law (shari'a) has not been taken as a sole source of legislation and, the state has not been subject to religious requirements in its internal and external policies. However, in contrast, Jordan was not established on the basis of 'radical secularism', which entangles a confrontational spirit with conservative and religious trends in the society ${ }^{3}$.

Despite the affiliation of the founding king to the 'Hashemite family', which belongs to the dynasty of the Prophet Muhammad, the Jordanian regime did not adhere to any religious descriptions, such as 'caliph' or 'Amir al-Mumineen,' (Prince of the Believers).

The successive Hashemite rulers in Jordan were keen to adopt a modern, secular form of state based on parliamentary monarchy, (a modern monarchy similar to European monarchies). However, the state did not abandon the religious dimension in its internal policies, and to a lesser extent in its

\footnotetext{
${ }^{1}$ Muhammad Aburman and Hassan Abu Haniyeh, (2012) "alhalu al'iislamii fi al'ardin", "The Islamic Solution in Jordan", issued by the Center for Strategic Studies, University of Jordan, and Published by: Friedrich Ebert Foundation, p.21

${ }^{2}$ Munib al-Madi and Sulaiman al-Mousa, (1988), tarikh al'urdun fy alqrin aleashrin (1900-1959), "The History of Jordan in the Twentieth Century (1900-1959)", Al-Muhtasib Library, Amman, edition 2, , vol. 1, p.108

${ }^{3}$ Muhammad Aburman and Hassan Abu Haniyeh, The Islamic Solution.., p. 21
} 
foreign policy ${ }^{4}$. It is also encouraged respect for religious sentiments prevailing in the society, and the protection of personal freedom and religious tolerance between different religions and sects.

Although King Abdullah I (1921-1951) showed interest in religious matters, most of this was in relation to public behavior, customs and traditions. In a directive to one of the prime ministers, he stressed that senior officials must abide by the requirements of prayer, fasting Ramadan, and that senior officials take care of these instructions and refrain from taking alcohol and gambling. He asked that the Government consider reducing the import of alcohol after its consumption had increased in the society ${ }^{5}$.

In a directive to Prime Minister Toufiq Abou El Hoda, the founding king Abdullah I ordered to make the hijab (headscarf) the proper garment for Muslim women to leave outside their houses. In his decree, the king warned that men roaming in the markets with their heads 'uncover' is contrary to what the ummah (Muslim community) inherited of virtues ${ }^{6}$.

On the other hand, ministries and institutions of the state issue instructions and regulations to urge respect for religious feelings and not to harm or disparage them, as happens in the month of Ramadan when the night clubs are closed, and the sale of alcohol during the day of Ramadan is prohibited ${ }^{7}$.

These directives and instructions have been exempted from deterrent penalties; no official laws have been issued, they remained mere advices. Jordanians understood that it is a matter of custom to adhere to this dress. This also shows that the King's first interest in religious matters was personal attention, which citizens did not exclusively commit to what he saw.

Religiously, the state stood on the 'neutrality', did not seek to impose the Islamic manifestations on the society, and at the same time did not promote a clear form of westernization, this is a consistent policy of the state since its founding ${ }^{8}$.

From its genesis, Jordan has been characterized as 'civil', not religious in the theocratic sense. It was clear from the outset that king Abdullah I, was keen to clarify its 'civil' political nature, which he had dedicated since May 15, 1923, (At the ceremony of the Declaration of Independence); 'I declare on this occasion that the Basic Law (Constitution) of the state will be prepared and the election law will be amended in accordance with the spirit, nature and social environment prevailing in the country' ${ }^{\text {". }}$

The definition of a religious state, whatever its religion, which is termed 'theocratic state', is a state in which its authority is held by a class of clerics, not by politicians. The cleric's rule is divine or holy; derived from the sacred religious texts. While any state not governed by clergy is necessarily a 'non-religious' state regardless of the nature of its regime; whether dictatorial, liberal, conservative, or military. Therefore, the state of Jordan is a secular state; there is no political authority for its clerics in any form.

Although the state of Jordan was not founded on religious grounds, the government has, ostensibly, taken on a conservative character, mainly due to the lineage of the royal family to Prophet Muhammad. This lineage supported the royal family with religious- historical legacy in establishing its 'symbolic' legitimate source to rule ${ }^{\mathbf{1 0}}$.

This 'balance' between religion and state has positioned Jordan in a category closer to 'Consensual Secularism'; whereby the state keeps its governing institutions and its internal and external policies as secular, at the same time; it does not clash with religion and respects its provisions in several legislations and policies.

\footnotetext{
${ }^{4}$ Ibrahim Gharaibeh, (n. d.), qura'atan fi alealaqat bayn aldiyn waldawlat fi aldustur waltashrieat al'urduniyati, A Reading of the Relationship between Religion and State in Jordanian Constitution and Legislation, Jerusalem Center for Political Studies, Amman, edition 1, pp. 14-15.

5 Tayseer Zebian. (1967). almalik eabdallah kama earafatuhu, "King Abdullah as I Know him", National Library and its Printing, Amman, p.57

6 Ibid. P. 66

${ }^{7}$ Ibid.

${ }^{8}$ Muhammad Aburman and Hassan Abu Haniyeh, The Islamic Solution.., p. 24

${ }^{9}$ Ibrahim Gharaibeh, (n. d.), A Reading of the Relationship...p. 3

${ }^{10}$ Muhammad Aburman and Hassan Abu Haniyeh, The Islamic Solution.., p. 25
} 
The state has maintained this trait since its inception to this time, and through generations of successive kings: Abdullah I, Talal, Hussein and Abdullah II. The country did not come out of this public line at any stage, and this 'balance' remained a key feature of Jordan's policy.

\section{The SECUlar ASPECTS OF THE CONSTITUTION}

There is nothing gray or ambiguous in the 'Articles' of the Jordanian Constitution that leads to the superiority of Islamic character of the state at the expense of the civil political system, nor are they hostile to the position of religion and its legislation. Article [6] (1) states that: "Jordanians shall be equal before the law. There shall be no discrimination between them as regards to their rights and duties on grounds of race, language or religion". ${ }^{11}$ This article made 'citizenship' a key feature of the state relationship with individuals and groups. The Jordanian nationality law no. 6 of 1954, defined 'Jordanian citizen' as such: "Jordanian" means any person who by virtue of this Law possesses Jordanian nationality'. The law did not stipulate origin, religion, color and language etc ${ }^{\mathbf{1 2}}$.

The Constitution of Jordan was adopted in 1952 and has been amended several times, most recently in 2016. Article 97 of Jordan's constitution guarantees the independence of the judicial branch, stating that judges are "subject to no authority but that of the law." Article 99 divides the courts into three categories: civil, religious, and special. The civil courts deal with civil and criminal matters, and have jurisdiction over all persons in all civil and criminal matters. And the jurisdiction of religious court extends to matters of personal status such as divorce and inheritance, and is based on Islamic law (Shari'a). The special court deals with cases forwarded by the civil one ${ }^{\mathbf{1 3}}$.

Article [14] states that: "The State shall safeguard the free exercise of all forms of worship and religious rites in accordance with the customs observed in the Kingdom, unless such is inconsistent with public order or morality” ${ }^{\mathbf{1 4}}$. This article guarantees citizens the freedom to believe in religion (any religion) and perform religious rituals.

The Constitution, which is the source of national legislation in Jordan, restricted religious laws only to cases of personal status. The Shari'a Courts alone have been granted the right of the judiciary in matters relating to the personal status of Muslims and matters of Islamic endowments.

Article [105] stated that: The Sharia Courts shall in accordance with their own laws have exclusive jurisdiction in respect of the following matters:

- Matters of personal status of Moslems.

- Cases concerning blood money (Diya) where the two parties are Moslems or where one of the parties is not a Moslem and the two parties consent to the jurisdiction of the Sharia Courts.

- Matters pertaining to Islamic endowments (Waqfs).

- While Article [106] states: The Sharia Courts shall in the exercise of their jurisdiction apply the provisions of the Sharia law ${ }^{15}$.

As for the personal status issues for non-Muslim Jordanians, the constitution assigned to the councils of religious communities, recognized by the government, the right of the judiciary in matters relating to personal status. Article [109] stated that: (i) Tribunals of Religious Communities shall be established in conformity with the provisions of laws pertaining thereto. Such laws shall define the jurisdiction of such Tribunals in matters of personal status and Waqfs constituted for the benefit of the

11 Constitution of the Hashemite kingdom of Jordan, Chapter Two (Rights and Duties of Jordanians), Article [6, 1], can get access [online] of this article on the website of the Parliament of Jordan at: http://www.parliament.jo/en/node/150, (last checked 2 January 2018)

12 Jordanian nationality law, Article 2, Law No. 6 of 1954 (last amended 1987), can get access[online] of this law at: http://www.refworld.org/docid/3ae6b4ea13.html, (last checked 18 May 202017)

${ }^{13}$ You can have a look at: https://en.wikipedia.org/wiki/Jordan. (last checked 25 October 202017)

${ }^{14}$ Constitution of the Hashemite kingdom of Jordan, Chapter Two (Rights and Duties of Jordanians), Article [14], [online] access of this article on the website of the Parliament of Jordan at: http://www.parliament.jo/en/node/150, (last checked 2 January 2018)

${ }^{15}$ Ibid. Chapter six (The Judiciary), Articles [105] and [106], 
community concerned. Matters of personal status of any such community shall be the same matters as are, in the case of Moslems, within the jurisdiction of the Sharia Courts. (ii) Such laws shall determine the procedure to be followed by the Tribunals of the Religious Communities ${ }^{\mathbf{1 6}}$.

Islam is the dominant religion in Jordan. Muslims make up about $92 \%$ of the kingdom's population and Christians today make up about $4 \%$ of the population. The website of 'Abuna'; (published by the Catholic Center for Studies and Media-Jordan), indicates that the proportion of Christian citizens in Jordan is $4 \%$ of the total population. The number of Christians in Jordan is estimated at 220,000 out of six and a half million according to the statistics of 2014-2015 ${ }^{17}$.

The country also has small religions, in terms of the number of associates, not recognized by the government as Baha'i and Druze religions.

Although the Constitution stated in Article [2] that: "Islam is the religion of the State and Arabic is its official language"18. This article does not assume any meaning other than that the majority of the citizens of the state are Muslims, and added to the Constitution as 'lip services' to appease religious and conservative forces.

The stipulation by the constitution that "Islam is the religion of the state", as well as, the existence of religious courts governing citizens in family matters, does not mean in any way that Jordan is a religious Islamic state. Article [24] (2) stated that: "The Nation shall exercise its powers in the manner prescribed by this Constitution" "19. Secular states drive their powers from constitutions, religious states from religious texts.

In the definition of the political system existing in the State of Jordan, the text of the Constitution in Article [1] stipulates that: The Hashemite Kingdom of Jordan is an independent sovereign Arab State. It is indivisible and inalienable and no part of it may be ceded. The people of Jordan form a part of the Arab Nation, and its system of government is parliamentary with a hereditary monarchy ${ }^{20}$.

This is the characterization of the political system in the Hashemite Kingdom of Jordan. Here we must note that the Constitution affirmed the 'Arab identity' of the Kingdom and its citizens, not 'Islamic identity'.

Article [24] (1) stipulate that: "The Nation is the source of all powers". And Article [25] says: "The Legislative Power shall be vested in the National Assembly and the King. The National Assembly shall consist of a Senate and a Chamber of Deputies"21.

According to radical Islamic discourse, in 'Islamic state' there is no place for nations to be the source of all authorities since 'Allah' (God) alone is the sole and absolute authority and governor, and there is no space for other than Islam (Quran and Sunnah) to be the source of legislations ${ }^{22}$.

In summary, the provisions of the Constitution appear to be clear on the civil nature of the political system and on the principle of equal citizenship in terms of rights and duties. The Constitution was clear in distinction and separation between civil and religious matters and, respecting different religions in terms of freedom of worship.

\footnotetext{
${ }^{16}$ Ibid. Articles [109]

17 A study prepared by Father Hanna Chaldani for The website of 'Abuna'; Issued by the Catholic Center for Studies and Media - Jordan, [online] available at: http://en.abouna.org/ , (last checked 16 July 2017)

18 Constitution of the Hashemite kingdom of Jordan, Chapter One, (The State and System of Government), Article [2], [online] access of this article on the website of the Parliament of Jordan at: http://www.parliament.jo/en/node/150, (last checked, 2 January 2018)

19 ibid. Chapter Three (Powers: General Provisions), Article [24] (2)

${ }^{20}$ ibid. Chapter One (The State and System of Government), Article [1]

${ }^{21}$ ibid. Chapter Three (Powers: General Provisions), Articles [24] (1) and [25]

${ }^{22}$ Hani, A. Shboul. (2017) "The Cultural Roots of Contemporary Islamic Terrorism and Ways of Confronting It", 'Asian Culture and History', Vol. 9, No. 2; 2017, Published by Canadian Center of Science and Education. Pp.30-31.
} 


\section{JORDAN'S COMMITMENT TO INTERNATIONAL AGREEMENTS}

Jordan signed and ratified a number of international conventions and agreements related to the human

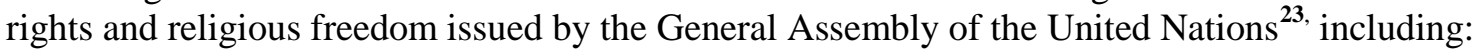

- The Universal Declaration of Human Rights of 1948, which states in article 18, "Everyone has the right to freedom of thought, conscience and religion; this right includes freedom to change his religion or belief, and freedom, either alone or in community with others and in public or private, to manifest his religion or belief in teaching, practice, worship and observance." ${ }^{24}$.

- The International Covenant on Civil and Political Rights (ICCPR) adopted by the United Nations General Assembly on 16 December 1966, and in force from 23 March 1976. It commits its parties to respect the civil and political rights of individuals, including the right to life, freedom of religion, freedom of speech, freedom of assembly, electoral rights and rights to due process and a fair trial ${ }^{25}$.

The (ICCPR) signed by Jordan on $28 \backslash 5 \backslash 1975$, and ratified on $15 \backslash 6 \backslash 2006,{ }^{26}$. The International Covenant on Civil and Political Rights (ICCPR) states in Article 18:

- Everyone shall have the right to freedom of thought, conscience and religion. This right shall include freedom to have or to adopt a religion or belief of his choice, and freedom, either individually or in community with others and in public or private, to manifest his religion or belief in worship, observance, practice and teaching.

- No one shall be subject to coercion which would impair his freedom to have or to adopt a religion or belief of his choice.

- Freedom to manifest one's religion or beliefs may be subject only to such limitations as are prescribed by law and are necessary to protect public safety, order, health, or morals or the fundamental rights and freedoms of others.

- The states parties to the present Covenant undertake to have respect for the liberty of parents and, when applicable, legal guardians to ensure the religious and moral education of their children in conformity with their own convictions.

According to constitutional expert lawyer Dr. Amjad Shamout, "the status of these agreements, like other ratified international conventions is higher than the law in practice, but less than the Constitution"."This means that the priority is given to the convention in the event of conflict with the application of the law, and the priority is given to the constitution if it conflicts with the convention"27.

Shamout points out that, although, the Jordanian constitution is clear regarding the application of religious freedoms and practices of religious rites that do not violate public order in Jordan, it did not stipulate that the country's authority must apply Islamic law (shari'a), or form its polices (internal and external) according to Islamic teaching ${ }^{28}$.

\footnotetext{
${ }^{23}$ International Human Rights Conventions And Jordan's Position, The National Centre for Human Rights (NCHR), [online] available at: http://www.nchr.org.jo/User_Site/Site/View_Article.aspx?\&Ic=1\&type=1 $\& \mathrm{ID}=312$ \&name=International\%20Human\%20Rights\%20Conventions\%20and\%20Jordans\%20Position , (last checked 3 January 2018)

${ }^{24}$ The Universal Declaration of Human Rights (UDHR), (last checked 3 January 2018) [online] available at: http://www.un.org/en/universal-declaration-human-rights/

${ }^{25}$ International Covenant on Civil and Political Rights (ICCPR), (last checked 3 January 2018) [online]

available at: http://www.ohchr.org/EN/ProfessionalInterest/Pages/CCPR.aspx

${ }^{26}$ The International Bill Of Human Rights, The National Centre for Human Rights (NCHR), (last checked 3 January 2018) [online] available at: http://www.nchr.org.jo/User_Site/Site/View_Article.aspx?\&Ic $=1 \&$ type $=2 \& \mathrm{ID}=1018 \&$ name $=$ The $\% 20$ International $\% 20 \mathrm{Bill} \% 20$ of $\% 20 \mathrm{Human} \% 20$ Rights

${ }^{27}$ Author's interview with constitutional expert Dr. Amjad Shamout, Head of Arab Permanent Committee on Human Rights-League of Arab States, and President of Arab bridge center for developments and human rightsjordan.the interview held on 25.06.2017.

${ }^{28}$ Ibid.
} 


\section{THE STATE'S IDEOLOGY AS DEFINED BY THE KING}

Jordan's King Abdullah II, in his sixth discussion paper entitled "The rule of law and civil state", issued on October 16, 2016, outline the identity of the Jordanian state as a civil state"29.

Jordan is a constitutional monarchy, but the King holds wide executive and legislative powers.

$\mathrm{He}$ is the Head of the State and Commander-in-Chief and appoints the prime minister and heads of security directorates. The prime minister is free to choose his own cabinet. However, the king may dissolve parliament and dismiss the government ${ }^{30}$. The current monarch, Abdullah II, ascended the throne on February 7, 1999 after the death of his father, King Hussein.

The king defined the principles that constitute the essence of the civil state: A civil state, he affirms, "is one that is governed by a constitution and laws that apply to all citizens without exception. It is a state of institutions that guarantee separation of powers through a system of checks and balances, preventing any power from encroaching on the other. It is a state built on peace, tolerance and harmony and is distinguished for respecting and safeguarding pluralism, respecting different opinions and protecting all members of the community, regardless of their religious or intellectual affiliation. It is a state that protects rights and guarantees freedoms, where all are equal in their rights and obligations. It is a state to which citizens resort when their rights are violated. It guarantees religious freedom for its citizens and enroots tolerance and respect of others in society. It protects the rights of women and minorities" ${ }^{\mathbf{3 1}}$.

Another sensitive aspect of the civil state addressed by the King's paper is the relationship between religion and state.

The paper emphasized that a 'civil state' is not 'synonymous with a secular state', in the sense of detaching religion from the public sphere. "In a civil state, religion is a key contributor to the value system and social norms", and "religion is also enshrined in our [Jordanian] constitution". But meantime, as the discussion paper plainly stipulates, "the state does not allow anyone to manipulate religion to serve political interests or gains for a specific faction",32.

With this qualification, King Abdullah was illustrating the complete structure of what the democratic civil state of the Hashemite Kingdom of Jordan would ultimately be.

Broadly speaking, secular states do exclude religion. While they do not ban people from practicing their religious beliefs, or restrict religious freedom, they do not allow religion to interfere in the affairs of the state, in order to avoid possible contradictions in societies that include various religious communities $^{33}$.

In this sense, the Jordanian model is unique. Although religion is enshrined in the Jordanian constitution, the constitution safeguards pluralism, guarantees freedom of religion, equality before the law of all citizens ${ }^{34}$.

\footnotetext{
${ }^{29}$ In December 2012, King Abdullah II announced that he would be issuing a series of discussion papers to share his vision on the kingdom's comprehensive reform process. So far, he issued seven papers. These papers have stimulates thought and dialogue between all Jordanians, and helped in accelerating and strengthening the reform process.

${ }^{30}$ See Jordanian constitution, chapter IV, part I, articles 30-40, on the website of the National Center for Human Rights: (last checked 2 January 2018), [online] available at: http://www.nchr.org.jo/User_Site/Site/ View_ Article.aspx \&Ic=1\&type=2\&ID=1033\&name=Constitution $\% 20$ of $\% 20$ the $\% 20$ Hashemite $\% 20 \mathrm{Kingdom} \% 20 \mathrm{of}$ $\% 20 J$ ordan

31 Abdullah II bin Al Hussein, "The rule of law and civil state", discussion paper, October 16, 2016, (last checked 21 December 2017), [online] available at: https://kingabdullah.jo/en/discussion-papers/rule-law-andcivil-state

${ }^{32}$ Ibid.

${ }^{33}$ Hasan Abu Nimah, "King's clear definition of civil state", The Jordan Times, Nov 08, 2016, (last checked 21 December 2017), [online] available at: https://jordantimes.com/opinion/hasan-abu-nimah/king\%E2\%80\%99sclear-definition-civil-state

${ }^{34}$ Ibid.
} 
The concept of 'civil state' is a new and emerging slogan in the Arab world. The concept has been successful and accepted as an alternative to the slogan of a 'secular state' which has been distorted by Muslim fundamentalists.

The sixth paper, authored by the King, reaffirms the civic ideology that the Jordanian state is pursuing. The characteristics of the 'civil state' set by the king conform to the characteristics of the 'secular state'.

However, to reassure conservative groups, he said that the civil state is not synonymous with the secular state. The king has defined the role of religion only in building a system of ethics and community values, keeping it outside the state functions, and refusing to exploit religion in political affairs.

The concept of a civil state is the same as the concept of a secular state; a state in which religion is separated from its political (internal and external), legislation, and institutional affairs. But secularism has acquired negative connotations amidst the majority of the Arab masses. The political elites found their shadow in the concept of the civil state and they are offering it as an alternative to secularism to avoid engaging in confrontations with the stream of political Islam and even with the general public.

According to Muhammad Qatatsha; professor of political science at Jordan's Mutah University, and a former member of Jordan's House of Representatives, "the nature of a civil state is to be secular, the relationship between them is reciprocal, and there is no conceivable civil state without being secular"."In the civil state, it is necessary to neutralize the role of religion in political practice and the administration affairs. This is secularism in its true form, which is inherent to civil state" ${ }^{\mathbf{3 5}}$.

"The civil state is a state ruled by law, and its citizens are equal before it, regardless of their beliefs, attitudes, race and sex. It stands at a same distance from all its social components, without any ideological bias to any component" ${ }^{\text {"36 }}$.

Although, the King's paper mentioned that a "civil state" is not "synonymous with a secular state", that does not change the secular nature and reality of Jordan; its institutions, and the relationship between it and its citizens, and does not reduce that secularism is the political space of the Jordanian state; even if it is 'relative' or 'incomplete'. In other words, Jordan's secularism is one form of secularism that reconciling with religion.

\section{ESCAPE FROM SECUlarism to CiVIL STATE}

Extremist Muslims have been successful in distorting the image of secularism in the collective consciousness of the Arab societies, and have created a psychological complex rooted in the subconscious and internal thinking that secularism is 'atheism' and it aims to fight Islam and perverse Muslims.

In their view, secularism is not a sweeping historical phenomenon. It is seen as a collection of Western ideas formulated by some Western thinkers, and these ideas originated in Europe because of the nature of Christianity; which separate religion from state, and because of the corruption of the church rule. Thus, secularism is only a Western Christian phenomenon; therefore, it has nothing to do with Islam and Muslims. Some Islamists, go even further, and argue that the process of transferring and applying secular ideas into the Muslim world takes place through a global conspiracy called (crusade) or (Jewish) or (Western) $!^{37}$.

They made many do not differentiate or distinguish between secularism as a way of tolerance and peaceful coexistence, and the ideological and intellectual position in rejecting or accepting religion

\footnotetext{
${ }^{35}$ Author's interview with Muhammad Qatatsha; Professor of Political Science at Jordan's Mutah University, and a former member of Jordan's House of Representatives, on 14.7.2017.

${ }^{36}$ Ibid.

${ }^{37}$ Hani Ahmed Shboul, (2017), WHY SECULARISM FAILED TO BECOME AN ARAB SOCIO-POLITICAL CULTURE? International Journal of History and Philosophical Research, Vol.5, No.5, Published by European Centre for Research Training and Development, p. 8,
} 
(any religion). Secularism is not only necessary for the coexistence of faith and atheism but also in the coexistence of religions and religious sects with one another ${ }^{38}$.

Therefore, political and intellectual elites in the Arab world use the term 'civil state' rather than 'secular state' because of the media demonization exercised on the concept of secularism by individuals and parties of political Islam in the Muslim world. Indeed, this term has been associated with Westernization, cultural hegemony, and anti-religion in the radical Islamic discourse.

Secularism has become a common product experienced by dozens of nations and civilizations, not just a thought, practice or experience imported from the West or the East. However, there is more than a secular model, not a single model that is comprehensive and closed. To avoid criticism and accusation, Jordan created its own secular model; (Secular Harmony) that preserves modernity of the state and its institutions, meantime maintaining respect for the special sphere of religion and its institutions.

\section{DISCUSSION}

The civilized world has for centuries realized that in order to succeed; modern nation-states must separate issues of religion from the issues of the state. Separating religion: which is divine and nonnegotiable, from the state's affairs, which are mundane, negotiable and apply to all citizens, does not reduce the importance of religion?

Faith is a spiritual relationship between humans and God. It is a sacred relationship that should be kept very personal and private.

Jordan's constitution stipulates that there shall be no discrimination in the rights and duties of citizens on grounds of religion, but also notes that the state religion is Islam and the king must be a Muslim. Article [28,5] states that: "No person shall ascend the Throne unless he is a Moslim, mentally sound and born by a legitimate wife and of Muslim parents" ${ }^{39}$.

Removing Article [2] of Jordan's Constitution, which states that Islam is Jordan's state religion, is important to eliminate the concept of state religion.

Having a state religion and, stipulating that the king (who is the head of the state) must be a Muslim are actually institutionalizes discrimination among citizens on the basis of faith and, contradicts Article [6] of the Constitution which states clearly that Jordanians are equal, irrespective of their religion.

The Monarch of the Hashemite Kingdom of Jordan is direct descendant of the Prophet Mohammad. There is no contradiction between this fact and the need for modern Jordan to shake off its attachment to concepts like state religion. The time has come for a new look at the role of religion in the governance of the state ${ }^{40}$.

Jordan has been blessed with liberal leadership (The Hashemite) that looks at religion in an open and moderate manner. It has all the qualifications, as well as a successful track record in governance, to be able to direct the country towards broader secularism.

\section{CONCLUSION}

From the definition above; Jordan is not a religious country, in the theocratic sense. In root, it is a secular state, in the sense that there is a separation between the country's political and religious institutions. While keeping the state's internal polices, legislations and international relations independent and separate from religion, Jordan does not exclude religion from the public sphere,

\footnotetext{
${ }^{38}$ Ibid. p. 9

${ }^{39}$ Constitution of the Hashemite kingdom of Jordan, Chapter Four, (The Executive Power), Part I, The King and His Prerogatives, Article [28, 5], [online] access of this article on the website of the Parliament of Jordan at: http://www.parliament.jo/en/node/150, (last checked, 2 January 2018)

${ }^{40}$ Daoud Kuttab, (2015), 'Religion should not be used to fight radicalism', The Jordan Times, Nov 18,2015, (last checked 15 December 2017) [online] available at: http://www.jordantimes.com/opinion/daoudkuttab/religion-should-not-be-used-fight-radicalism
} 
rather includes the religious institution in the positive, spiritual role that contributes to the development of society's moral values, underscoring an exceptionally important equation embodied in the 'balance' sustained between Godly and worldly matters.

\section{AUTHOR'S BIOGRAPHY}

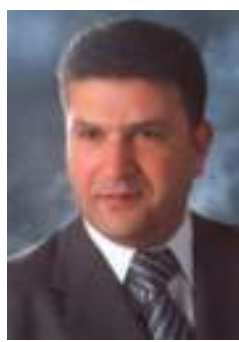

Dr. Hani Ahmed Shboul, obtained Bachelor Degree in political science from Gujarat university-India, master degree in political science from M.S. university of Baroda-India, and $\mathrm{PhD}$ in contemporary History (political Islam vs. modernization), from the university of Mumbai-India. The author presently is working as an assistant professor, at the Department of Basic Sciences, Al Balqa'a Applied University Jordan. The author contributed papers to Arabic and international journals. He is interested more, but not limited, in research work related to religion and politics, secularism, and culture.

Citation: Hani Ahmed Shboul. "The Relationship between Religion and State in Jordan: (Historical Perspective)”. International Journal of History and Cultural Studies (IJHCS). vol 4, no. 1, 2018, pp. 47-55. doi:DOI: http://dx.doi.org/10.20431/2454-7654.0401003.

Copyright: (C) 2018 Authors. This is an open-access article distributed under the terms of the Creative Commons Attribution License, which permits unrestricted use, distribution, and reproduction in any medium, provided the original author and source are credited. 